\title{
Jak tedy reflektovat socialistickou pedagogiku?
}

\author{
Kamil Janiš ml. \\ Slezská univerzita v Opavě, Fakulta veřejných politik v Opavě, Ústav pedagogických \\ a psychologických věd
}

Diskusní příspěvek reaguje na článek prof. Maňáka - Pedagogika a pedagogové v období vlády komunismu (Pedagogická orientace, 23(3), 386-391). $\mathrm{V}$ úvodu je nutné poznamenat, že jsem nastoupil do 1 . tř́́dy v roce 1990 a s pedagogikou v době socialismu v ČSR (později ČSSR) mám tedy zkušenosti pouze z jeslí (což si nepamatuji) a z mateřské školy, z níž si určité útržky pamatuji. Avšak jako pětiletému dítěti mi to bylo úplně jedno a nedocházely mi přirozeně žádné souvislosti. I přes uvedený handicap, který je však i jistou výhodou, si dovoluji zapojit se do diskuze. Článek prof. Maňáka je reakcí na obdobné diskuzní příspěvky, a to J. Mareše (2010), J. Průchy (2011) a úvodníku T. Svatoše (2010). Maňák (2013) trefně upozorňuje, že i některé články či publikace kromě dobře zpracovaných a využitelných informací obsahují i ideologicky zaměřené pasáže, s kterými rozumný člověk nemůže v plném rozsahu souhlasit, a ke kterým se přiřazuji i já.

Období socialismu (1948-1989) a jeho reflexe z pedagogického aspektu je přirozeně oblastí, která bude zajímat především vědecké pracovníky v oblasti pedagogiky a nestane se celospolečenským tématem. Jisté fragmenty, a to zejm. socialistické školství, mají šanci proniknout (a pronikají) do tematicky zaměřených projektů, které mají za cíl přiblížit zmiňované období a jeho zvrácenost. Jak k reflexi přistupovat? Jednou z možností je paradoxně takový přístup $\mathrm{k}$ historii, ve kterém je přistupováno $\mathrm{k}$ dějinám jako $\mathrm{k}$ faktu, který se stal, bez vlastního hodnocení s pouhým faktografickým výčtem informací bez vlastního kritického názoru1. Takový př́istup $\mathrm{k}$ dějinám pedagogiky využil O. Kádner (1870-1936). Jeho přirozenou výhodou je, že dává prostor pro vlastní kritický pohled, nepodsouvá vlastní pravdu apod. V souvislosti $\mathrm{s}$ tématem příspěvku však vyžaduje znalost př́ślušných společenských poměrů. Na to upozorňuje i Maňák (2013) a daná poznámka vyplývá z logiky věci, a to i bez explicitního zmínění.

Zřejmě bude panovat všeobecná shoda, že takový přístup by pouze poskytl materiál k dalšímu zpracování a i výše je uvedeno, že se o žádnou reflexi

\footnotetext{
1 V trojsvazkové publikaci Dějiny pedagogiky od O. Kádnera, lze najít hodnotící soudy, nikoliv však jeho vlastní, ale parafrázované. Je tak podán maximální objektivní názor na daného pedagoga, pedagogický směr či období.
} 
nejedná. K reflexi musíme tedy přistoupit tak, aby se jednalo o reflexi. Reflektovat můžeme jednak kompletní práci jednotlivých pedagogů, či selektivně vybírat i v současnosti podnětné myšlenky či návrhy s obšírnějším kontextovým zasazením tak, aby byl podán objektivní náhled. A právě takový způsob mě přivádí $\mathrm{k}$ dalším otázkám. Měli bychom pozitivně hodnotit i myšlenky či názor pedagogů a „pedagogů“, jejichž smýšlení bylo vždy nedemokratické a až fundamentalisticky komunistické? Objektivně se přikláním k názoru, že ano, ovšem za podmínky dehonestujícího dovětku. Při znalosti či přečtení celého díla takových „pedagogü“ a celkového zasazení do širšího rámce dané problematiky (socialistické nebo komunistické výchovy) není dohenstujícího dovětku potřeba. Zjevná nedemokratičnost a jistá manipulace ve výchově (zejména fragmentace obsahu) vyplyne z textu sama. Pokud však část myšlenek vytrhneme z kontextu, zjistíme, že je nutné je reflektovat. Níže jsou uvedeny dva př́lklady $\mathrm{k}$ výše napsanému.

Již od nejútlejšího věku je třeba stavět dítě do takových situací, aby žilo, hrálo si, pracovalo, sdílelo radosti i žal s jinými dětmi. Je třeba, aby tento společný život byl pokud možno radostný, plný jasu. (Krupská, 1951, s. 91-92)

Nejlepší osnovy a učebnice nám nic nepomohou, když nebudeme mít vynikající učitele. (V. I. Lenin in Mejstř́ík et al., 975, s. 5)

Pod výše uvedené citace bychom se pravděpodobně všichni podepsali. Ale nikdo z nás by je nepropagoval, kdyby věděl, od koho jsou. Přirozeně jsou uvedené př́klady vytrženy z celkového kontextu smýšlení. Pouze ilustrují objektivní obtížnost reflexe socialistické pedagogiky. Ovšem i fundamentálně komunisticky založené osobnosti nelze ignorovat a apriori je odsoudit proto, že s jejich názory nesouhlasíme. Jak jsem poznamenal výše, nenalezneme jich mnoho. Je však nutné se zabývat i takovými „pedagogy“, a to i přesto, že jejich „vzletné“ myšlenky vycházely vždy z komunistické ideologie, kterou nikdy neopustili a projevovala se ve všech jejich činnostech. Ještě bych rád zdůvodnil, proč je slovo pedagog $v$ daném kontextu v uvozovkách. Jednoduše proto, že se jedná o lidi, které rozhodně za pedagogy primárně nepovažujeme. Důležitost reflexe i takových osobností a pedagogických názorů je důležitá především v kontextu současné politické situace. Současná KSČM musítleskat nad volebními programy parlamentních i neparlamentních demokratických stran, které v oblasti vzdělávací politiky až překvapivě shodně naplňují slova K. Gottwalda, V. I. Lenina, N. K. Krupské a některá usnesení ÚV KSČ aj. ${ }^{2}$

2 Přirozeně již v demokratickém „hávu“, nicméně základní myšlenka je shodná. Tato skutečnost by tedy měla být důvodem $\mathrm{k}$ reflexi. 
Dvořák (2013, s. 8) upozorňuje na skutečnost, že některé texty staré několik desítek let působí tak, jako by vznikly dnes ${ }^{3}$. I když se měnily podmínky, tak určité problémy přetrvaly. „Že by to tedy nebylo jen v podmínkách, které rádi kritizujeme, ale částečně také v nás?"4

Obtížnější situace nastává u pedagogů, kteří jsou svým způsobem sporní a kontroverzní svými názory, svou osobností. Maňák (2013), ale i Mareš (2010) uvádějí celkem známý případ $\mathrm{M}$. Cipra, kdy na jedné straně je zmiňován jeho spor s V. Př́íhodou 5 , a na straně druhé zpracoval M. Cipro několik kvalitních publikací. M. Ciprovi bývá vytýkáno tzv. „převlečení kabátů“. Tím se ovšem zabývat nechci, a to především z důvodu, že M. Cipro již nemá možnost se k tomu vyjádřit, a považuji za neférové jednání uvádět pouze jeho př́́klad, stejně jako výše zmiňovaní autoři. Měly by se však sledovat i motivy takových pedagogů. Nechci však být zároveň prvním, který „vystřelí“ do pedagogů žijících a aktivně působících. Na rozdíl od předchozího příkladu je tedy reflexe takto kontroverzních pedagogů složitější především z důvodu, že na jedné straně „škodili“, ale na straně druhé přinášeli relativně kvalitní publikace.

Obdobné př́klady nalezneme i v současnosti, kdy se ve srovnání s obdobím socialismu zpravidla nejedná o kompromitující kampaň jednoho vůči druhému. Není ale výjimkou, že odborný spor v otázce určité oblasti pedagogiky přeroste do roviny negativních poznámek a osobních invektiv. ${ }^{6}$

Maňák (2013, s. 390) hovoří v souvislosti s M. Ciprem ještě o jednom př́kladu, když předkládá jeho návrh řešení konkrétní výchovné situace, kdy je matce doporučováno, aby využila metodu výstrahy v souvislosti s pozdním príchodem syna. Má synovi pohrozit, že pokud by se jeho pozdní příchod opakoval, tak to oznámí pionýrskému vedoucímu. J. Maňák sarkasticky poukazuje na „vědeckost“ takového názoru a celkovou absurdnost. Přirozeně to $\mathrm{v}$ současnosti působí komicky a dává to vzpomenout cimrmanovskou zásadu trestání učitele učitelem. Ovšem obdobných příkladů, které dnes působí komicky, a to nejen z období socialismu, bychom našli desítky až

3 V oblasti dějin pedagogiky lze nalézt několik př́íkladů, které jsou staré stovky let a jejichž aktuálnost je zarážející.

4 D. Dvořák v odstavci, ze kterého je citováno, reaguje na článek J. Mareše, který je zde uváděn.

5 M. Cipro nebyl jediný, kdo ostře kritizoval V. Př́ihodu. Dlouhodobé spory s ním měl také 0 . Chlup a řada dalších pedagogů.

$6 \quad \mathrm{~V}$ podstatě jsme denně svědky negativisticky vedených kampaní, kde je snahou a touhou „zničit“ druhého, a to i s využitím nedemokratických zásad. 
stovky. Stejně tak bychom našli i př́íklady metod výchovy, které nelze vědecky ověřit. Jak uvedený příklad reflektovat? Modifikací. Obdobné doporučení nalezneme např. v publikaci od R. Čapka - Odměny a tresty ve školní praxi (2008, s. 54-55), kdy je tedy výstraha směřována od učitele žákovi a je mu pohrozeno, že jeho chování bude oznámeno řediteli. I Ciprovo zdánlivě komické doporučení můžeme modifikovat do současnosti, kdy takto může být postupováno $\mathrm{v}$ př́ípadě, že dítě uznává a záleží mu na názoru někoho jiného než rodiče (např̀ učitele).

Název mého př́íspěvku však zní - Jak tedy reflektovat socialistickou pedagogiku? Maňák (2013) tvrdí, že by se měli pranýřovat pouze ti autoři, kteří prokazatelně „škodili“ jiným a v podstatě tak celé společnosti. Avšak i takoví autoři měli nějakou překvapivě pozitivní myšlenku, nad kterou bychom se měli pozastavit. Dále jsou J. Maňákem předložena objektivní kritéria při posuzování počinů apod. jednotlivých autorů. Se všemi lze jednoznačně souhlasit, avšak jedno si dovolím nastínit i v jiném světle. Možná překvapivě se jedná o věrnost demokratickým ideálům. Zcela samozřejmě jsem zastáncem takových ideálů, ale otázka zní: Máme se tímto kritériem ř́dit pouze u socialistické pedagogiky? Proč taková otázka? Pokud bychom dané kritérium přijali jako obecné ve vztahu k reflexi obecně dějin pedagogiky, tak by byl na „černé listině“ zapsán: J. L. Vives (1492-1540), který ve svém díle ponižoval ženy, na druhé straně nadčasově přispěl k oblasti sociální práce. Dále J. Locke (1632-1704), který se vzděláváním žen a chudých téměř vůbec nepočítal, avšak docenil význam všeobecného vzdělání a mravní výchovy jedince. Abychom ještě zůstali u „pěkného“ vztahu k ženám, zmíním A. Schopenhauera (1788-1860), pro kterého byla žena jakýmsi „póvlem“. A. Schopenhauera sice chápeme primárně jako filozofa, který významu výchovy nevěřil vůbec. Avšak byl zastáncem jakési výchovy pro život, kdy se vzdáleně dotýká (což nemohl tušit) myšlenek amerického pragmatismu J. Deweyho (1859-1952). Pokud bychom tedy přijali kritérium ctění demokratických ideálů, které vede k černobílému rozdělení pedagogů a pedagogiky období socialismu jako jedno ze základních, museli bychom pak zdůvodnit, proč tak nepostupujeme $v$ kontextu celých dějin. Lze demonstrovat ještě jeden př́klad, kdy demokrat z nejdemokratičtějších v oblasti výchovy a vzdělávání by byl zřejmě I. Illich (1926-2002), pod jehož návrhy bych se nepodepsal.

Reflexe období socialistické pedagogiky v letech 1948-1989 má své logické opodstatnění. Nemělo by však být postupováno systémem černá vs. bílá, zlý vs. hodný apod. Objektivně bychom měli pozitivně hodnotit i „pedagogy“, 
kteří i zdánlivě svobodomyslnými myšlenkami sledovali jistý „Zvrácený“ cíl7, který naplnit nehodláme. Možná to zní jako oxymóron - pozitivně hodnotit zvrácený cíl. Ale i zajímavou a do jisté míry aktuální myšlenku můžeme podat v negativních konotacích, kdy nedojde ke glorifikaci dané osoby.

At’ se nám to líbí či ne, každý demokratický i právě nedemokratický systém potřebuje získat na svou stranu učitele a všechny ostatní pedagogické pracovníky, kteří se podílejí na výchově. Z tohoto aspektu je možná edukační systém vnímán jako významný nástroj $\mathrm{k}$ naplnění cílů nedemokratických systémů a je mu přikládána významná role $\mathrm{v}$ celém společensko-politickém kontextu. Je i více propracovaný. I to je námět $\mathrm{k}$ tomu reflektovat pozitivní stránku daného období, jak vyzývá v závěru svého příspěvku prof. Maňák.

Závěrem bych rád doplnil, že rozhodně nejsem zastáncem komunistické ideologie a jsem rád, že většinu svého života jsem prožil, prožívám a budu prožívat v demokratické společnosti.

\section{Literatura}

Dvořák, D. (2013). Orbis scholae je v databázi SCOPUS. Orbis scholae, 7(1), 7-9.

Krupská, N. K. (1951). $O$ výchově a vyučování. Praha: SPN

Mareš, J. (2010). O vstupování na tenký led. Pedagogika, 60(2), 99-103.

Maňák, J. (2013). Pedagogika a pedagogové v období vlády komunismu. Pedagogická orientace, 23(3), 386-391.

Mejstř́k, V., et al. (1975). Čeští učitelé na cestě k socialismu. Praha: SPN

Průcha, J. (2011). Vstoupit, či nevstoupit na tenký led analýzy socialistické pedagogiky? Pedagogika, 61(2), 187-190.

Svatoš, T. (2010). Aby pedagogika byla vědou provázenou historickou reflexí. Pedagogika, 60(1), $1-3$.

7 Vzbuzování dojmu svobodné volby či deklarace neexistence manipulace je jedním z charakteristických rysů totalitních režimů. 